\title{
2.
}

\section{Mafia and the representation of Italians}

\section{Giulio Pitroso}

Transactions of the Digital Games Research Association

December 2019, Vol. 5 No 1, pp. 45-76. ISSN 2328-9422

(C) The text of this work is licensed under a Creative

Commons Attribution - NonCommercial -NonDerivative

4.0 License (http://creativecommons.org/licenses/by-ncnd/ 2.5/).

IMAGES: All images appearing in this work are property of the respective copyright owners, and are not released into the Creative Commons. The respective owners reserve all rights

\section{ABSTRACT}

This study analyses the representation of Italians and the Mafia in video games. It analyses games of different genres with Italian organized crime as the main theme: they differ in terms of gameplay and narrative, though they all have important features in common. The study compares movies about organized crime and video games, in order to understand the relation between themes and genres in these two media. Furthermore, the paper examines both narrative aspects and game design, and is intended to raise questions concerning the genre of Mafia games. It also analyzes the role of Italian ethnic background, as well as the role played by gender and sexual orientation, and relates those elements to 
the values commonly associated with the Italian Mafia. Finally, the study highlights how games represent more general stereotypes that are associated with Italian culture, such as the consumption habits of food and music. The methods of this research are based on semiotic analysis, sociolinguistics and Cultural Studies.

\section{Keywords}

Mafia, Italy, Italian-Americans, Sicilian language, management games, action games, casual games

\section{INTRODUCTION: MAFIA and the video games}

\section{Mafia games: goals, problems, and methods}

This essay analyzes a selection of video games that have the Italian Mafia as their main theme. While different types of 'mafia' have been present in various geographical and historical contexts, the 'Italian Mafia' refers to the criminal organization that is characterized by its historical, cultural and political connections to the Italian Republic. As such, this study excludes other criminal organizations that are referred to as 'Mafia', and have goals, strategies or internal structures that resemble those of their Italian counterparts, but have participants that are not of Italian descent. The study aims to identify the common characteristics of these games, and to provide the means to understand the representation of Mafia(s) through this medium. The paper examines both narrative aspects and game design, focusing on how the Mafia is represented within different genres (i.e. strategic games, RPG, etc.). Looking at the narrative of the games, the paper analyzes the sociolinguistic mechanisms involved in the representation of the characters' Italian ethnic background, as well as the role played by gender and sexual orientation, and evaluates how these features can be seen to replicate or challenge pre-existing values and beliefs commonly associated with the Italian Mafia. Finally, the study highlights how games represent more general stereotypes that are 
associated with Italian culture, such as habits of food consumption and music preferences.

The investigation starts with The Godfather (US Gold, 1991), the earliest representative of the genre. I decided to begin with this text because it is the first to contain clear references to the world of Italian organized crime. It is also explicitly inspired by the world of cinema. Indeed, its importance is tied to the centrality of Coppola's saga in the history of cinema. These movies played an important role, as we shall see, both in the history of the Cosa Nostra and in creating narrative models and stereotypes about it. The essay draws on articles and texts that have analyzed the representation of Mafia in both film and television, and compares the key characteristics of these forms of representation with what is visible in video games.

The ultimate goal of this study is to raise questions concerning the construction and cataloging of a genre. For this reason, it mixes taxonomic methods and textual criticism, and is intended as a first step towards a more structured study. Moreover, the analysis encourages a study of the reception of these cultural products, for two key reasons. First, Mafia is inevitably linked with political problems and contexts. Cultural products that do not explicitly condemn this type of criminal organization might risk legitimizing them. Second, games and other types of texts about, or incorporating, Mafia organizations might have a direct influence on those players who experience these forms of crime in their daily lives, as they might consider becoming part of them if these are not only normalized, but also made attractive by cultural products.

In carrying out this study, I conducted research on Moby Games, YouTube and Steam, using keywords such as 'Mafia', 'mobster', 'gangster', 'criminal organization', etc. I found several games involving Mafia. I then selected only those games that included the Italian Mafia in their thematic and substantive content. I played the identified games either on Steam or via a free internet download. Some of these games were unavailable, so I decided to watch them 
on YouTube. Research and analysis were undertaken of those titles relevant to the themes of this paper: they will be mentioned in this study. The study also draws on the author's own knowledge and experience.

\section{The Godfather, an archetypal model}

The strongest stereotype through which Italians have been represented is probably the one tied to the Mafia. This ominous link has its roots in the representations of Italian-Americans that were popularized in Hollywood films, especially since the 1930s era of gangster movies. It created an inseparable bond between white ethnicity and organized crime, according to a discriminatory scheme that had already been applied to other social groups, albeit with different fields of afference. As noted by Cortés (1987, pp. 109-111), the film industry gave to Chinese, Irish, and especially Italians the role of gangsters, but it had already created recurring associations between ethnicity and role that were equally discriminatory, such as Mexican bandits, bloodthirsty natives, and savage and uninhibited African-Americans (this question will be taken up in the section titled 'Gangster or Mafioso?'). The gangster film played a particularly important role in describing the internal contradictions of the 'American Dream' and the conflicts between an open society and capitalism, as evidenced by the famous work of Robert Warshow (Shapiro, 1993, p. 731). The gangster movie shed light on the dilemma between ruthless individualism and the risks attached to this (Bernardelli, 2016, p. 11), and even the conflict between the ethics of rural society (code of honor, importance of family, monoculturalism, etc.) and those of modern society (personal success as the principal aim of the individual, diminution of collective interests, etc.). The role played by Italian minorities therefore represented an internal threat to American society, more shocking and dangerous than those performed by other groups. This is important, because in all video games about the Mafia, we can find a reference to a clash between different systems of ethics. As we will see later, this situation was revolutionized by The Godfather (Coppola, 1972), which replaced 
instances of archaic society and pre-urban ethics with the rules of the Mafia and of the ethnic group, always at odds with the heartless reasons of business. In addition, Cortés also notes how the Mafia movie is intended to reflect the broader concerns of all Americans: 'Coppola used the Mafia as a metaphor for the American quest for wealth and power, in which the Mafia symbolizes the successes and excesses of American big business' (1987, p. 118).

Coppola's saga enjoyed an incredible level of success, and had a significant impact on the collective imagination. The success of the film is linked to two problems in representing the Mafia: on the one hand, the criminalization of an ethnic group, and on the other, the risk of giving legitimacy to a dangerous organization. The first problem is linked to the so-called 'marketing of ethnicity' by Hollywood between 1970 and 1988, which gave new dignity to groups that had previously been discriminated against on the screen, and it allowed Italian-Americans to take a leadership role in the system of production in creative industries (Cortés, 1987, p. 116). Ethnicity also became a marketing tool, and public interest in the topic grew. However, in the US, it became commonplace to associate Italian origins with connections to the Mafia. Moreover, as noted by Cortés, from that point onwards, the Italian or ItalianAmerican characters whose ethnic origin was not relevant to the plot were often portrayed as gangsters. The Godfather - and subsequent movies that exploited its success - provoked mixed reactions throughout American society: they created a cultural phenomenon, as set out in a successful book, namely The Godfather Effect (Santopietro, 2012). On the one hand, as Santopietro writes, Italian-Americans happened to appear more civilized and more humane, and young people with non-American origins were moved to get in touch with their roots. On the other hand, it consolidated a stereotype. Much of the literature on Coppola's saga focuses on the humanization of mobsters, and how the titular character appears as a good family man. The 'family' is also the name of a hierarchical system, headed by a don, or godfather, who derives his authority from his wisdom and his respect for his subordinates. This is something of a novelty, if 
we compare it to the socially dangerous outcast protagonist of gangster movies (Cawelti, 1975, pp. 339-340). The Mafia is represented as an organization dominated by strict rules. Those secret rules were discovered thanks to the revelations of Valachi, the informer and protagonist of The Valachi Papers (Young, 1972). Coppola's Mafiosi are seeking their identity, while encountering and attempting to navigate the stark contrast between the needs of the business and those of an ancient, almost feudal, code of honor. We must also note that the Mafia is a deeply rural phenomenon (Dalla Chiesa, 2015). Vito Corleone fights against the introduction of drug trafficking in New York, because he deems it a threat to the respectability of the Mafia among both the Italian community and his allies who have political power. Michael Corleone tries to strike a balance between his process of cultural assimilation into American society and his role as capofamiglia, trying disastrously to become an honest entrepreneur. The tragic position of Corleone is no longer that of the classic gangster who pursues success at all costs: they must choose between free market society and the traditions of the ethnic group, reconsidering their role within the Italian community.

The Godfather film also had a relationship of mutual influence with the real-life Cosa Nostra and indeed prompted protests from some Italian-Americans. In particular, the Association of ItalianAmerican Civil Rights League staged vigorous protests, until its leader, Joseph Colombo, made a deal with the production company. Colombo was a member of one of the 'Five Families' and established an agreement that the film would make no mention of the word 'Mafia' (Rossen, 2017). This is an important point, because, as we will see later, similar controversies have also accompanied the release of video games about the Mafia. In essence, The Godfather marked a pivotal point in the history of representation in this regard, providing the main template for Mafia games. 


\section{Mafia and video games}

The video game industry started releasing games about the Italian Mob in the 1990s. The Godfather (US Gold, 1991) - playable on Amiga, MS-DOS, Atari ST - is the most famous example. As an archetypal model in this genre, we will analyze the game below. There were several earlier games that referred to the Mafia or to the gangster film. Most of these do not have a criminal as the principal character: mobsters are the enemy. For this reason, they do not fulfill our definition of Mafia games. Here is a short list of examples:

\begin{tabular}{|c|c|c|c|}
\hline Video game & Kind of criminals & $\begin{array}{c}\text { Why it is not a Mafia } \\
\text { game }\end{array}$ & Year \\
\hline $\begin{array}{c}\text { Hogan's } \\
\text { Alley }\end{array}$ & $\begin{array}{c}\text { Fake, cardboard } \\
\text { gangsters are targets } \\
\text { for shooting practice. } \\
\text { They recall classic } \\
\text { gangster movies }\end{array}$ & $\begin{array}{c}\text { The lead character is an } \\
\text { FBI agent }\end{array}$ & 1984 \\
\hline $\begin{array}{c}\text { Chicago } \\
1931\end{array}$ & $\begin{array}{c}\text { Reference to } \\
\text { gangster movie }\end{array}$ & $\begin{array}{c}\text { The lead character is an } \\
\text { FBI agent }\end{array}$ & 1986 \\
\hline Gumshoe & $\begin{array}{c}\text { King Dom is a Mafia } \\
\text { Boss }\end{array}$ & $\begin{array}{c}\text { The settings are surreal, } \\
\text { with fantastical elements } \\
\text { and the mob boss is not } \\
\text { Italian. The lead character } \\
\text { is a private eye }\end{array}$ & 1986 \\
\hline La Cosa & $\begin{array}{c}\text { Our enemies are } \\
\text { imaginary members } \\
\text { of the Chicago Outfit }\end{array}$ & $\begin{array}{c}\text { The lead character is a } \\
\text { private eye }\end{array}$ & 1986 \\
\hline Dead Angle & $\begin{array}{c}\text { Reference to } \\
\text { gangster movie }\end{array}$ & $\begin{array}{c}\text { The lead character is a } \\
\text { young man whose } \\
\text { girlfriend has been } \\
\text { kidnapped by the Mob }\end{array}$ & 1988 \\
\hline
\end{tabular}

Unlike these games, The Godfather has a series of elements that characterize it as a prototype of the Mafia game: 
1) The moral dilemma linked to the code of honor: when the player kills civilians (three times) - in our gaming experience - he will be disowned by the family and the game will end.

2) The settings: the places described are related to those of Coppola's saga (New York, Las Vegas and La Havana) and other places inspired by the films. They reveal that the predominant point of view is that of the Mafia in North America and Sicily.

3) The narrative structure refers to a social tradition and it is strongly tied to the history: the game opens with an introduction explaining the existence of the Five Families, and each level is associated with one year (1946, 1957, 1961, 1975, 1981). The Mafia families are considered as social groups that evolve over time.

4) The role of the anti-hero: the criminal we control acts against the law.

5) Corrupt law enforcement: in all levels, there are policemen whose role is to stand by and watch our crimes and eventually be killed. This detail emphasizes the existence of a gray area, referring to the relationship between the Mafia and political power.

During the game, there are also some frames visible from movies with Al Pacino playing Michael Corleone. In fact, when the game was released, the creative and commercial process around video games was asymmetrically dependent on movies: for the most part, games were adapted from, and playable versions of, successful works from the silver screen. As Alexis Blanchet has noted, there were two ways to undertake this adaptation: one, a multigenre approach, in which there were several ways to interact - e.g. puzzles, driving simulation, etc. - with the gameplay; and two, a monogenre approach (2008, p. 47). The latter option was more related to the plot of the movie, as in The Godfather. The game combines first- and third-person shooting. Hence, looking at the relation between media, we can recognize in The Godfather 
some interesting elements, which signal the interface between the Italian Mafia and video games: the significant role played by movies, and the reworking process that served to narrate the Mob within a new medium.

\section{The Mafia game}

In relation to the games mentioned above, we can cite two titles in order to foster a more complex discourse. There are two video games - The King of Chicago (Mindscape/Cinemaware, 1987) and Mafia (Igelsoft, 1986) - set in Chicago with a gangster as the protagonist. The first combines a rudimentary graphic novel and first-person shooting, with multiple choice dialogs: we can perform criminal actions and build an empire, taking advantage of the chaos facilitated by the arrest of Al Capone. Yet, the very story of the game poses problems in recognizing the importance of the authority of the Mafia system, and our protagonist, Pinky Callahan, is not Italian. Even if corruption does arise, and some protagonists are of Italian origin, the lack of a code of honor means that it is not, strictly speaking, a Mafia game. Even Mafia, which is more focused on gang management and profits, is not a Mafia game: it presents almost anonymous protagonists, the Mafia rules are almost absent, and the hierarchical system within the gang is weak. The strategic map of the city allows us to choose a scenario (e.g. robbery, fights, etc.) to play out, or to start a textual adventure. Nevertheless, the story has minimal internal coherence. For example, we can be pickpockets on the metro one minute, and storming an armored car the next: real Mafiosi do not behave like pickpockets. In essence, the social culture of the Mafia is absent in both of these games.

The Italian Mafia has its own mythology and ideology, which have been studied since the Mob started to become a social and political problem. It is a complex phenomenon that has provoked much dialog within cinema and television. This dialog has had unexpected effects. For instance, it has been observed that The Godfather had an impact on the behavior of real gangsters of 
Italian origin in the United States (Adler, 2006), who started to imitate the characters of the movies. The history of the Mafia is bound up with the conditions of Southern Italy, which became the central pillar of the so-called 'southern question' a few years after the country's unification. Whilst the North was developing infrastructures and systems of production, the South remained a largely backward, agriculture-driven society in which the social texture was significantly different. The ancient and almost tribal code of honor that inspired gangsters was born there and had an influence among Italian communities abroad, since the south contributed substantially to the Italian diaspora (Coppola, 1997, pp. 150-160), and - as will be explained below - to the creation of the Italian Mob's international network, including multiple countries such as Argentina, Australia, Canada, Japan and the United States. Furthermore, all the original criminal organizations that today we call Mafias have their origins in Southern Italy: the Cosa Nostra in Sicily; the Camorra in Naples; the 'Ndrangheta in Calabria. Whilst the first is well known, the others have only been represented in literature, film and TV in the past decade or so, following the success of Gomorrah (Sorrentino, 2008). Nevertheless, the Sicilian Mafia has always had a hegemonic role in representing the Italian Mafia (Santino, 2014).

In the field of video games, most titles about the Italian Mob are centered on 'This Thing of Ours' (American) and 'Cosa Nostra' (Sicilian). Moreover, the games that feature Italian organized crime as a secondary element of the story follow the same model. When there is no visible explanation of the ties to Italy, they appear throughout Italian culture - food, music, habits, and moral code - non-verbal communication and languages - Sicilian, ItalianAmerican or Italian - and the names of people or places, which clearly have Italian origins. These are intended to convey the characters and the social texture related to them. We could also have included in this study games that depict Cosa Nostra models and behavior elsewhere, such as Scarface: The World Is Yours (Radical Entertainment, 2006), and explore this mafia-related cultural zone of approximation. It would probably prompt us to 
discover the effects of the influence of this cultural model upon other kind of games - e.g. in fantasy ones, where it is possible to frighten gamers so as to create racket systems, or in open world games where players set up illegal smuggling. Unfortunately, we can only suggest that these and other interesting game playing practices are inspired by 'pure' Italian Mob titles.

\begin{tabular}{|c|c|c|c|c|}
\hline Company & Video game & $\begin{array}{c}\text { Type of Italian } \\
\text { Mob }\end{array}$ & $\begin{array}{c}\text { Where the game is } \\
\text { set }\end{array}$ & Year \\
\hline $\begin{array}{l}\text { Rockstar } \\
\text { Games } \\
\text { (USA) }\end{array}$ & $\begin{array}{c}\text { Grand Theft } \\
\text { Auto III }\end{array}$ & $\begin{array}{c}\text { Leone crime } \\
\text { family* (This Thing } \\
\text { of Ours) }\end{array}$ & Liberty City* & 2001 \\
\hline $\begin{array}{l}\text { Eidos } \\
\text { Interactive } \\
\text { (UK) }\end{array}$ & $\begin{array}{l}\text { Gangsters 2: } \\
\text { Vendetta }\end{array}$ & $\begin{array}{l}\text { Reference to the } \\
\text { National Crime } \\
\text { Syndicate and } \\
\text { Chicago Outfit, } \\
\text { gangs of mixed } \\
\text { origins }\end{array}$ & New Temperance* & 2001 \\
\hline $\begin{array}{l}\text { Electronic } \\
\text { Arts }\end{array}$ & $\begin{array}{c}\text { The } \\
\text { Godfather }\end{array}$ & $\begin{array}{l}\text { The Five Families } \\
\text { (with false names as } \\
\text { in the movie) }\end{array}$ & New York & 2006 \\
\hline $\begin{array}{l}\text { 2K Games } \\
\text { (USA) }\end{array}$ & Mafia II & $\begin{array}{l}\text { Sicilian Mafia, This } \\
\text { Thing of Ours }\end{array}$ & Sicily, Empire Bay* & 2010 \\
\hline $\begin{array}{l}\text { Kalypso } \\
\text { Media } \\
\text { (DE), FX } \\
\text { Interactive } \\
\text { (ES) }\end{array}$ & $\begin{array}{l}\text { Omerta: The } \\
\text { City of } \\
\text { Gangsters }\end{array}$ & $\begin{array}{l}\text { National Crime } \\
\text { Syndicate, gangs of } \\
\text { mixed origins, } \\
\text { Sicilian Mafia }\end{array}$ & $\begin{array}{l}\text { Atlantic City, Japan } \\
\text { (in the Japanese } \\
\text { Incentive DLC) }\end{array}$ & 2013 \\
\hline
\end{tabular}

Table 1: This table shows some of the most important examples of mafia games. The names of the organizations and places with * do not exist.

In Table 1, we can observe the ethnic origins of video game gangsters. At a glance, one can speculate about the connections between the Italian Mob and its Sicilian origins. It seems that the only Italian Mafia is Cosa Nostra and that the American-Italian one is a direct expression of the migration process from Sicily. Figure 1, taken from Mafia II, better explains this point. Here, the wiseguy Jimmy looks at the Sicilian flag, in an American-Italian bar. Throughout all of the adventures of Mafia II, the Italian flag 
is prominent on the walls or above shop doors, as a symbol of an immigrant community. Nevertheless, only at a Mob meeting point do we find a clear sign of the Sicilian identity. Furthermore, a chapter of the game is set in Sicily: Sicilian-speaking rebels rise up against fascists, aided and managed by an important boss, clearly inspired by Calogero Vizzini. In Mafia II it is also possible to read the following loading quote: 'A man must be able to claim Sicilian or Italian descent to become a member of the American Mafia. Non-Italians are often associated with the Mafia, but can never join the organization itself'. There is a clear distinction between Italy and Sicily, which is historically based, since Sicily aspired to be independent in the late '40s (Nicolosi, 1981) and its identity has been a matter of public debate in Italy. Nevertheless, Italy is made up of four other autonomous regions, each with strong local identities, and, beyond three traditional mafias, there were (and remain) other criminal organizations. One should add that the Italian Mafia, as mentioned before, is spread across several countries, as an effect of the Italian diaspora. There is, for example, an Argentinian-Italian Mob (Aguirre, 2000); there are sections of the Calabrian 'Ndrangheta in Canada and Australia; and the Italian Mafia is even present in the UK. These groups have been depicted, respectively, in the TV series Hombres de honor (Polka, Argentina, 2005), Bad Blood (City, 2017-ongoing, Canada), Peaky Blinders (BBC Two, 2013-ongoing, UK), and Underbelly Files: Infiltration (Nine Network, 2011, Australia). The TV series Gomorrah (Sky Atlantic, 2013-ongoing, Italy) enjoyed international success: it is based on the tragic lives of the Neapolitan Camorra's mobsters. Hence, we can assume that this Sicilian-American hegemony is the result of the American point of view that dominates almost all of the games, and The Godfather model as the first archetype of a Mafia game. 


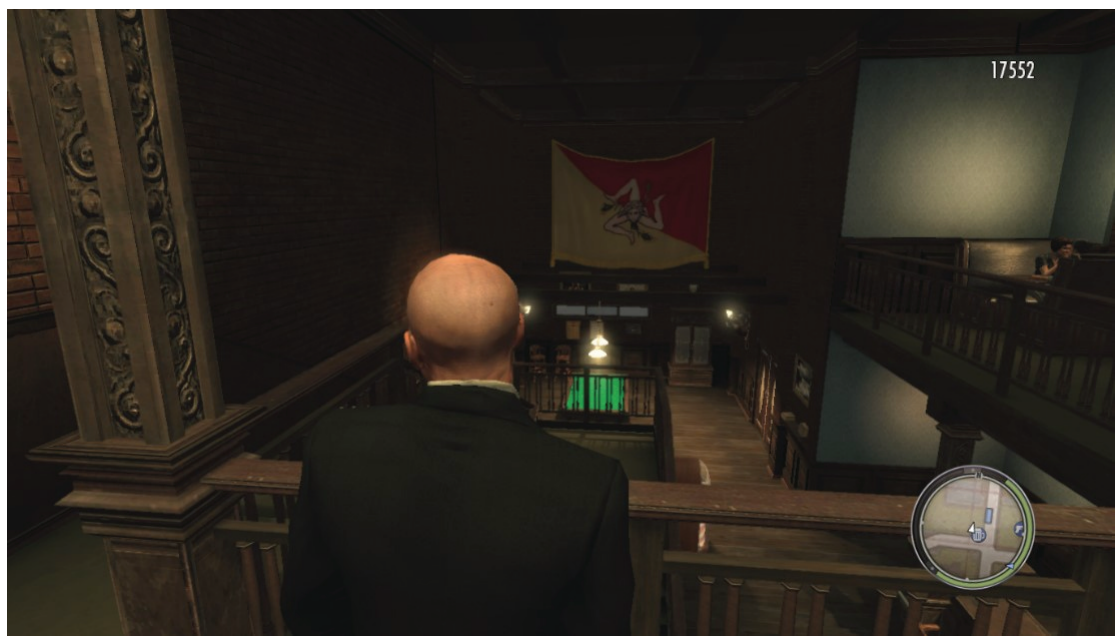

Figure 1: Jimmy, the lead character of Jimmy's Vendetta, an expansion of Mafia II, looking at the Sicilian flag in a bar owned by the Mafia.

In order to evaluate this argument, we might consider that the aforementioned games are set in New York, Atlantic City and fictional places that recall famous American cities. New Temperance State resembles the Lake Michigan area, while Liberty City and Empire Bay are New York. The same geographical discourse should be made about other titles: New Temperance is also the set of Gangsters: Organized Crime (Eidos Interactive, 1998), which is the previous chapter of Gangsters 2, while Vice City of Grand Theft Auto: Vice City (Rockstar Games, 2002) resembles Miami. Sicily is always seen from the American perspective: in Omerta our character comes from Sicily to pursue the American dream; Vito Scaletta lives out his adventures as an American soldier in Sicily; Massimo Torini comes from Sicily to Liberty City with a secret plan to enable Sicilians to rule in America in Grand Theft Auto: Liberty City Stories (Rockstar Games, 2006).

By contrast, Italian creative industries - TV and cinema, above all - are always called upon to respond to the critical debate around this theme. Such discourse includes video games as well. As a result, it is not unusual to see political campaigns against 
them: in this regard, we might cite the deputy of Sicilian Regional Parliament Cracolici who tried to block the release of Mafia II in Italy, so as to avoid 'l'equazione Sicilia-uguale-mafia' ('the equation that Sicily equals mafia'). The same game was also accused of racism by the Italo-American Association, while the Italian MEP Sonia Alfano demanded that it be blocked. On the first accusation, Take-Two responded by saying that the company had the objective of distinguishing the artistic expression from the gratuitous use of violence and stereotypes (Purchese, 2010). As to the second charge, $2 \mathrm{k}$ Games replied: 'Mafia II tells a compelling story about organized crime in America - a subject that for decades has been featured in award-winning movies, television shows and novels such as The Godfather and The Sopranos' (Dutton, 2010). This discourse is analogous to the reception of other cultural products related to the Mafia, especially when they come from the other side of the Atlantic. This was the case with the television series The Sopranos (1999-2007), of which, on Columbus Day 2004, the then-President of the Chamber Gianfranco Fini said: 'Italian Americans are a positive force and no television series can erase it’ (Longo, 2004).

The cultural conflict around this topic has likely contributed to the dearth of Italian video game productions that make use of the Mafia. However, we should also note two hidden references to the Mafia in Italian video games: Wheels of Aurelia (Santa Ragione, 2016) and Memory Reloaded (La Molleindustria, 2004). The first is related to a quote from Pasolini, while the second refers to the memory card of the corrupted 'First Republic'. Hence, to even speak about this argument in a non-pedagogical way seems to be difficult in the Italian context. 


\section{TOOLS FOR UNDERSTANDING MAFIA IN VIDEO GAMES}

\section{Convergence Culture and the representation of Mafiosi}

Our starting point in this section is Henry Jenkins' Convergence Culture (2006). In the chapter entitled 'Searching for the Origami Unicorn: The Matrix and transmedia storytelling', dedicated to The Matrix, Jenkins sets out how video games, movies and cartoons interact to create a form of transmedia narration. Some missions from Enter the Matrix (Shiny Entertainment, 2003) reveal parts of the story that are not present in the film, and yet they remain coherent with it. Even the archetype of Mafia games is based on a famous series of films, but in the first The Godfather game we are only able to live out the adventures of a gangster in the places established by the movies. In the 2006 version, our principal character is Aldo Trapani, who does not appear in the films: his missions disclose parts of the story that we could only have imagined. For example, Aldo must deliver the head of the horse, Khartoum, to the bed of the Hollywood producer, Woltz.

Nevertheless, the relation of continuity between video games and movies, and the expansion of the story, has to be seen in relation to other important aspects, one of which is legitimacy. Famous actors voiced the characters they had originally portrayed in the movies, giving legitimacy to the game: a key exception in this regard is that of Al Pacino, who instead chose to play Tony Montana in Scarface. While the Wachowskis had the opportunity to set up a collaborative writing network, instead of a synergic action (2006, p. 99), The Godfather had to deal with two obstacles. The games were released decades after the movies, at which point it would have been impossible to imitate Wachowskis' process, that is, creating the expansive universe of The Matrix, as it was an ongoing process. Furthermore, Coppola was openly opposed to the video game, stating: 'I had absolutely nothing to do with the game and I disapprove. I think it's a misuse of film'. There are also notable market-driven processes at work in the adaptation of movies and TV series for other media that differed from those of 
The Matrix: in the latter case, they had the aim of anticipating the development of the plot or connecting sequels to previous movies. Jenkins notes that not only did they have a working peer-to-peer network, but they also took part in the mixed media strategy, which generated flexible characters tied to what he calls the franchise (2006, p. 105). Nevertheless, this is not the case with The Godfather. Once Coppola's filmic trilogy had come to an end, it was quite unlikely that the video games could prompt or contribute to the release of a new chapter of his work. Producers propose a reading pathway that begins with the book, passes through the movie, and arrives at the video game (Davis, 2008, p. 240). This process follows the chronological order of the creation of the works attached to the same story. Davis notes that in the first passage, the story undergoes narrative compression, while in the second, it is given a narrative expansion. Nevertheless, we know of a few games that have partly inspired movies, even some involving the Italian Mob: this is the case with Hitman 2: Silent Assassin (Eidos Interactive, 2002) and the films Hitman (2007, France, USA, UK) and Hitman: Agent 47 (2015, USA). In the game, the famiglia Giulianis kidnap the mentor of the principal character, the Sicilian priest Vittorio, while the story of the films is different and does not include this character. In any event, the debate over the relations between cinema, TV series and video games is not our chief focus here; we merely have to acknowledge some key elements before proceeding any further. We would agree with the following claim: 'we realize that films do not serve as models for games, but provide a set of necessary viewing space techniques that the video game takes and adapts to its own needs' (Perron and Arnault, 2015). Nevertheless, the mafia movies/mafia games relation is asymmetric: the role played by the silver screen is still dominant in the making of video games, and, hence, in the depiction of Italian mobsters. However, we will show below how a specific group of games is reframing the representation of the Mafia. 


\section{Gameplay}

In terms of gameplay analysis, the Mafia games are a mixture of several genres. The most famous examples are clearly derivatives of GTA III, which was 'strongly influenced by the gangster-movie' (Blanchet, 2008): the Mafia and The Godfather series are a combination of racing, shooter and beat 'em up games. Strategic and management games - like the Gangster series and Omerta - are based on point and click interaction: they are usually RTS games, like the multiplayer casual games adapting the spirit of mobster capitalism to a mobile device, Mafia Wars (Zynga, 2009) or Mob Wars (Maestri, 2008). All of these games have two key aspects in common: they have a strong predisposition for openworld settings, and they often use RPG dynamics. For example, in the strategic game, Gangsters 2, we can move our characters on the map and deal with missions as we want, although the level requires a general objective to be achieved within the allotted time. We can also manage our personnel in legal and illegal activities, suffering the effects of financial losses and losing the game altogether in the case of bankruptcy. The role every character has or the abilities the player can unlock, as well as the points they receive at the end of a level, are typical of RPG. A similar scheme can be found in The Godfather, where the ranks are inspired by real roles within Cosa Nostra, while in Mafia II the development of a criminal carrier is tied to the objects taken, thanks to gamer abilities (clothes, cars, light weapons), or given during the campaign (heavy weapons, special cars, houses). Therefore, Vito Scaletta becomes a made man in a specific chapter of Mafia II. There are several variations on the theme, but role-play and action are always central features of any Mafia game. This happens because hierarchy and illegal activities are intimately connected to this criminal phenomenon. Even when it is used to create a funny and intriguing framework in the blackjack simulation game, Mafia Gambling (Gamenesis, 2018), the Mafia is tied to ranks: one of the playable characters, Umberto Calderone, has the aim of demonstrating his success in gambling so as to become the boss of his family. 


\section{Gangster or Mafioso?}

We have seen how Mafia movies and games are deeply intertwined. In recognizing this, some important questions emerge. First, what is the meaning of 'Mafia' and what is its relation to gangsterism? Once again, we will take, as our example, Mafia Gambling (Gamenesis, 2018). The game presents itself on Steam with the following: 'Welcome to the Criminal Town full of gangsters and mafioso'. The game is not really a Mafia game, as we have seen before. Nevertheless, it does represent an interesting use of the terminology. Not all games have distinct members of the Mafia and gangsters, and casual games in particular often do not follow this pattern. In Mafia Wars, a successful social media strategy game, we can start as 'Street Thug' - which reminds us of modern gangs - with the aim of becoming 'Capo', 'Consigliere', 'Underboss', and 'Boss'. Although the other levels we can reach are not explicitly related to the Mafia, it is fused with other elements in order to create a criminal organization scenario. Moreover, these ranks are similar to those we can achieve in 2006's The Godfather. Hence, Mafia is somehow used as a synonym for organized crime. However, it is evident that Mafioso carries an ethnic connotation that we should use with caution.

Film studies has dealt with this issue by defining and distinguishing between the Mafia movie and the gangster film. Of course, American movies about gangsters have a long tradition: in their golden age, the gangster was presented as a problematic character, whose aspiration to success pushes him to a tragic death. He is often represented as an outcast, placed in a harsh urban setting, or as a member of a specific ethnic group, particularly Italian, whose moral conduct is shown to be highly controversial, if not wholly reprehensible. Despite his success, the gangster's 'final downfall did not purge a festering uneasiness that he was a growing menace and natural by-product of the consumer-driven economy' (Pauly, 1998, p. 779). This scheme is apt even for Irish-American criminals (Shannon, 2005). As Stefano Becucci notes, gangsters are 'sons of modernity', while Mafiosi derive their 
strength and rootedness from tradition, intertwining it with modern social skills (Becucci, 2013). A Mafioso must observe strict rules and discipline, with access to significant resources.

As noted earlier, Coppola's The Godfather was a significant cultural moment insofar as it changed people's perceptions of the Mafia. In light of this, Larke-Walsh uses the term 'postclassical' to refer to all films and TV series that came after The Godfather:

The reason for this is because I feel that while The Godfather is an example of postclassical filmmaking, all subsequent gangster films are defined by their relation to The Godfather as much as if not more than in their relation to classical films. In short, I wish to demonstrate how the films of the last 40 years present coherences reminiscent of a 'continuous text' that draws upon the classical period, but is mainly influenced by The Godfather. (2010, p. 4)

Cortés gives the same importance to the movie when he describes it as a point of reference within the history of cinema representing Italian-Americans: 'The post-Godfather movie trajectory of Italian-Americans has been, to a great extent, an offshoot or a response to this icon-solidifying masterpiece, a film that in itself integrated the major threads of seventy years of US screen treatment of Italian-Americans' (1987, p. 108). After this film, there seemed to be a clearer distinction between gangsters and Mafiosi. The Italian Mafia uses external relations, corruption and politics. Even if not fully accepted by society, the Italian made man is more socially respectable than the simple gangster, and his moral code plays an important role. In my view, the films about the Italian Mafia that come after The Godfather have to be seen as examples of the Mafia movie, a sub-genre of the gangster film.

As we have seen, American movies play a major role in how the Mafia is depicted in video games. For instance, we can see the face of Al Capone on the cover of Gangsters 2, and the atmosphere of Omerta and Chicago 1930 (Spellbound Entertainment, 2003) draws from the Prohibition era. Nevertheless, we also have to consider another perspective. The Italian Mafia movie has its roots 
in a mixture of genres; first, the Western (and the Spaghetti Western), political cinema (inspired by journalistic inquiries), then erotic and grotesque comedy: it was set in Sicily, which was painted as an exotic and mysterious Far West (Morreale, 2007). The Italian-style comedy occupies a midway position between the cinema politico and so-called B movies starring famous comic actors (Leotta, 2011). The Italian Mafia movie is more politically focused and often presents the Mob as a problem, albeit sometimes a comic one. In any event, journalism and comedy have had an important influence on this kind of movie. We can recognize some elements of the Italian Mafia movie in Mafia III (2K Games, 2016). The way the characters are presented and the way they explain the story of Lincoln are inspired by docufiction. The people who knew Lincoln, the Afro-American protagonist, tell his story: either they speak directly to the camera (e.g. Father James), or some 'authentic footage' is provided from other sources (e.g. John Donovan speaking to the Senate Hearing), while other cut scenes depict dramatized reconstructions. Lincoln is a former associate of the Italian Mafia who struggles to take revenge against the local boss in New Bordeaux - a fictional version of New Orleans: his marginal perspective narrates the Mob, underlining the problem of racism.

Hence, it is clear that movie genres served to influence how games about the Mafia are produced. While the American Gangster Film, both classical and postclassical, showed the Italian Mob, docufiction and the Italian Mafia movie presented the problematic aspects of this phenomenon. This discourse brings us to a key question: to what extent has this process of intermedia adaptation altered the representation of Italians in the Mob? 


\section{ITALIAN CULTURE AND STEREOTYPES}

\section{Italian Culture}

As noted above, Italian culture can be seen to permeate Mafia games in various ways. Yet, we ought to distinguish those games that have the Italian Mob as a primary element of the story from those that feature it as merely a secondary element. In Mafia II we can recognize aspects of the first model. Here we recognize some typical Italian stereotypes from the movies: Italians have greasy hair, a propensity for violence, they use specific nonverbal communication, etc. Nevertheless, the game has an incredible degree of accuracy and coherence. In this light, we might imagine that the game actually mocks such stereotypes. Even the Italian characters on the sidewalks of the Empire Bay open world turn out to be darkly comical: for instance, they would say 'Basta, please!' or 'Per favore, stop!', if they are violently pushed to do so. The important characters speak Italian on special occasions, such as Vito Scaletta's initiation, when the master of ceremonies concludes by calling him 'Amico nostro'. In the World War II chapter, Don Calò and other Sicilians speak in correct Sicilian. Furthermore, Italian flags are everywhere in Italian neighborhoods, some even on walls. Our characters - we can play Joe Barbaro and Jimmy in three installments - dress in fancy suits like the other Italian mobsters, in a nod to the Italian taste for fashion. The Mafia run Italian restaurants, which serve drinks and coffee like other venues in the game, while the 'Italian Delicatessen' branding is printed on walls. Not all the songs on the radio pertain to ItalianAmerican identity, but some of the most famous ones certainly do. The latter are bound up with the tradition of The Godfather, such as 'Che la Luna' by Luis Prima, and Italian-Americans on the silver screen: for example, 'That's Amore' by Dean Martin or 'Mambo Italiano' by Rosemary Clooney. Even social aspects play an important role in communicating Italian stereotypes. Female characters play a secondary role in the game: except for his sister, mother and a sister of a mobster, Vito meets prostitutes, dancers and other female characters whose role is merely to pleasure him 
or his friends. Even women on the streets are only able to demand mercy. Women had lesser roles even in classical and 'postclassical' gangster films. As Carmela Coccimiglio has observed, 'the mother, the moll (girlfriend), and the wife' and 'a fourth role - the female gangster' are the main roles for women (2013, p. 20) in movies and TV series about the Mafia. The family itself is the locus of social relations: the name of the local criminal organization is la famiglia and it is supposed to be even more important than the natural one. Indeed, the natural family is a crucial part of the Italian-American stereotype (Parini, 2006, p. 71). Another interesting element is that of revenge: for instance, the name of one installment refers to 'Jimmy's Vendetta'. 'Vendetta' ('Revenge') is also used in English to denote a blood feud, but in this video game it appears to be used as a cultural reference to Italian culture. Revenge seems to be the final aim of the actions of almost all Italian mobsters in video games: Aldo Trapani, Vito Scaletta, Joe Barbaro, Jimmy and Lincoln Clay all deal with a world that is ruled by vendetta, with the latter providing the engine that propels their tragic adventures.

In games that deploy the Mafia as a secondary element, or in those that are more gangster-oriented than tied to the Italian Mob, not all of the aforementioned elements are always present. (See Table 2). 
Mafia and representation 67

\begin{tabular}{|c|c|c|c|}
\hline Video game & Italian Culture & $\begin{array}{l}\text { Italian } \\
\text { language }\end{array}$ & Social aspects \\
\hline $\begin{array}{l}\text { Grand Theft } \\
\text { Auto III }\end{array}$ & $\begin{array}{l}\text { 'Double Clef FM' is the } \\
\text { radio of the Italian Mob } \\
\text { playing opera music }\end{array}$ & $\begin{array}{c}\text { The members of } \\
\text { the Leone } \\
\text { family use } \\
\text { sentences in } \\
\text { Italian and } \\
\text { Sicilian }\end{array}$ & $\begin{array}{l}\text { Women as } \\
\text { secondary } \\
\text { characters, } \\
\text { prostitutes }\end{array}$ \\
\hline $\begin{array}{l}\text { Gangsters 2: } \\
\text { Vendetta }\end{array}$ & $\begin{array}{c}\text { The face of Al Capone on } \\
\text { the cover of the game; } \\
\text { names of the Italian } \\
\text { mobsters }\end{array}$ & & $\begin{array}{l}\text { Female managers } \\
\text { and gangsters; } \\
\text { the importance of } \\
\text { family (the uncle } \\
\text { of the principal } \\
\text { character is his } \\
\text { advisor); } \\
\text { centrality of } \\
\text { revenge }\end{array}$ \\
\hline This is Police & $\begin{array}{l}\text { Italian origins of one } \\
\text { gang member }\end{array}$ & & $\begin{array}{l}\text { Atala Funeral } \\
\text { Home is the } \\
\text { Italian gang, } \\
\text { whose leader is } \\
\text { Federica LaTerza }\end{array}$ \\
\hline $\begin{array}{l}\text { Omerta: The } \\
\text { City of } \\
\text { Gangsters }\end{array}$ & $\begin{array}{l}\text { References to the Italian } \\
\text { diaspora; names of } \\
\text { mobsters }\end{array}$ & $\begin{array}{l}\text { The reference to } \\
\text { Italian language } \\
\text { is in the name of } \\
\text { the game }\end{array}$ & $\begin{array}{l}\text { Female gangster } \\
\text { available; the } \\
\text { Tucci brothers } \\
\text { represent a funny } \\
\text { parody of Italian } \\
\text { family }\end{array}$ \\
\hline
\end{tabular}

Table 2: This table is just an example of the Italian culture and stereotypes in video games that feature the Mafia as a secondary element

\section{REFRAMING THE MAFIA: A CONCLUSION?}

New and interesting representations of the Mafia have started to appear, largely as a result of a form of crosspollination between gangster movies, Mafia movies, and some other genres. It is not unusual to watch gangsters who are simultaneously humorous and cruel; for instance, when Mr. Wolf came to the aid of two odd criminals in Pulp Fiction (Tarantino, 1994). As such, new representations have to reckon with a transformation in Italian Mob stereotypes. 
Several elements have contributed to the development of narratives around the Mafia. It is possible to see this process as an effect of the influence of postmodern cinema. Malavasi and Fassone summarize the key elements of this as follows: 'restructuring of the past, irony, meta-language' (2015, p. 128). Postmodern film influences the representation of the Mafia in video games. Guns, Gore and Cannoli (Crazy Monkey Studios, 2015) presents a funny mobster who deals with a zombie apocalypse: the game combines Italian body language, ItalianAmerican idiomatic expressions - such as 'Forget about it!' or 'Capisc?' - gangster stereotypes, and comic use of gory violence, horror and sci-fi genres. Even Omerta uses similar schemes, presenting Mr. Wolf in person as one of the specialists available for our criminal team. The game is replete with amusing quotes and plays with different genres of fiction: noir, gangster, pulp.

Another trend in the video games industry is that of reframing the Mafia from a critical perspective. As we have seen, Mafia III is narrated by the outcast, Lincoln. It depicts forces of racism and ties this to the Mob, to provide a debunking operation, not specifically against the Italian Mob, but rather to discover and explain the broader phenomenon of discrimination within the United States. This is Police (THQ Nordic, 2016) does something similar in conveying the power of Mobsters via the point of view of a chief of police who is about to retire. The sophisticated development of the story underlines the pervasiveness of corruption in society: gangsters seem to be merely a mirror in which the police can witness its own degradation.

The role played by Italian mobsters in video games is changing, though some core elements from the archetypal model are retained. The old stereotypes are still used in tandem with the mythological Mafia of The Godfather and with gangster films. Nevertheless, new elements seem to supplement and mutate these stereotypes, with the Mob often being used as a vehicle through which social problems can be analyzed and engaged with. Moreover, we can play funny games about the Mafia, and laugh at 
it in the process. The influence of films remains potent, but it is clear that Mafia games are something different. There are several common points between the games that are totally dedicated to the Mafia, and those that functionally use it as simply a part of the storyline by recycling Mafia stereotypes established in the movies, but deploying them in various ways or to different ends. In so doing, they partake in what Larke-Walsh calls the 'continuous text' of Mafia representation (2010, p. 4): for the scholar there is a coherent mythology that runs through the classical and 'postclassical' gangster films and TV series. For us, it seems that this continuous text must also be extended to incorporate video games.

This prompts us to pose new questions. In this study, we have not had the opportunity to discover how the games are perceived by gamers: this would constitute an excellent point of departure for a larger research project in this area. Furthermore, a more in-depth gameplay analysis would yield more points of consideration. A thoroughgoing analysis would no doubt provide many interesting and unexpected results.

In this light, it is worth mentioning the study by Jakobsson and Taylor (2003) on the influence of the Mafia in the online RPG, EverQuest. It seems clear that there is a contamination, which calls for further exploration. As such, we must resume the model of cinema and TV series to stimulate future studies on the effects of the representations of the Mafia on people, and specifically on those involved in criminal activities. During the creation of The Godfather, Marlon Brando met a real-life boss of our American Cosa Nostra; in addition, 'James Caan made such a point of studying the mannerisms of all the mobsters who were hanging around the set' (Gambino, 2012). It has also been documented that the New Jersey Mafia family took inspiration from the deeds carried out by certain characters in The Sopranos TV series (Viner, 2006). Might there be a similar influence between the creative industries and the Mafia? Does the reception of this kind of video game have an effect on Mafiosi? Such questions will be for others 
to answer in the future. But this study has sought to lay out the main outlines and foundations for such analyses.

\section{BIBLIOGRAPHY}

Adler, T., Hollywood and the Mob: Movies, Mafia, Sex and Death, London: Bloomsbury, 2008.

Aguirre, O., Historias de la mafia en Argentina, Buenos Aires: Aguilar, 2000.

Becucci, S., “Criminalità organizzata”. In M. Mareso and L. Pepino (Eds), Dizionario enciclopedico di mafie e antimafia, Torino: Edizioni Gruppo Abele, 2013.

Bernardelli, A., "Etica criminale? Le trasformazioni della figura dell'antieroe nella serialità televisiva”, Between, 6, no. 11 (Maggio/May 2016), http://www.betweenjournal.it/

Blanchet, A., “Cinema e videogiochi, le leggi dell'adattamento”. In M. Bittanti, Schermi interattivi, Roma: Meltemi, 2008.

Coccimiglio, C., Absent Presence: Women in American Gangster Narrative, Department of English, Faculty of Arts, University of Ottawa, 2013, retrieved from https://www.ruor.uottawa.ca/ bitstream/10393/26217/1/Coccimiglio_Carmela_2013_thesis.pdf, p. 20

Cortés, C., "Italian-Americans in Film: From Immigrants to Icons”, MELUS, 14 (1987), no. 3/4: 107-126.

Coppola, P., Geopolitica delle regioni italiane, Torino: Einaudi, 1997.

Cawelti, J. G., “The New Mythology of Crime”, boundary 2, 3 (1975), no. 2: 324-357. 
Dalla Chiesa, N., “Che cos’è la mafia”. In Lezioni di Antimafia, Raffaele Liguori in "Radio Popolare", retrieved from http://www.radiopopolare.it/2015/11/che-cose-la-mafia/

Davis, G., "The Warriors. Percorsi di consumo, rimediazione e narrazione transmediale”. In M. Bittanti, Schermi interattivi, Roma: Meltemi, 2008.

Dutton, F., "Mob violence victim calls for Mafia II ban”, Eurogamer, 17 febbraio 2010, retrieved from https://www.eurogamer.net/articles/2010-12-17-mob-violencevictim-calls-for-mafia-ii-ban

Galen, D., "The Warriors. Percorsi di consumo, rimediazione e narrazione transmediale”. In M. Bittanti, Schermi interattivi, Roma: Meltemi, 2008.

Gambino, M., “What is The Godfather Effect?”, Smithsonian.com, 31 gennaio 2012, retrieved from https://www.smithsonianmag.com/arts-culture/what-is-thegodfather-effect-83473971/\#A2OSB5A5KZOdMxXz.99

Gibson, E., “Coppola slams EA's Godfather game”, Gamesindustry.biz, 11 Abril 2005, retrieved from https://www.gamesindustry.biz/articles/coppola-slams-easgodfather-game

Jakobsson, M. and Taylor, T. L., "The Sopranos Meets EverQuest: Social Networking in Massively Multiplayer Online Games”, fineArt forum, 17 (2003): 8.

Jenkins, H., Convergence Culture: Where Old and New Media Collide, New York: New York University Press, 2006.

Larke-Walsh, G. S., Screening the Mafia: Masculinity, Ethnicity and Mobsters from The Godfather to The Sopranos, Jefferson, NC: McFarland \& Company, Inc., 2010. 
Leotta, A., "Do Not Underestimate the Consequences of Love: The Representation of the New Mafia in Contemporary Italian Cinema”, Italica, 88 (2011), no. 2: 286-296.

Longo, A., "Fini all' attacco dei Sopranos Serie tv contro gli italoamericani”. la Repubblica, 11 ottobre 2004.

Malavasi, L. and Fassone, R., "La stagione postmoderna”. In G. Carluccio, L. Malavasi, and F. Villa, Il cinema, Roma: Carocci, 2015.

Emiliano Morreale, Storia e illustrazione del mafia-movie in «Lo Straniero», n. 82, aprile 2007, link http://www.eleaml.org/sud/ mafie/lo_straniero04_2007_mafia-movie.html

Nicolosi, S., Sicilia contro Italia, Catania: Tringale, 1981.

Pauly, T., “The Criminal as Culture”. American Literary History, 9 (1997), no. 4: 776-785.

Parini, I., Italian American Gangsterspeak: Linguistic Characterization of Italian American Mobsters in Hollywood Cinema and in Italian Dubbing, Saarbrücken: LAP LAMBERT Academic Publishing, 2006.

Perron, B. and Arnauld, D., "De-framing Video Games from the Light of Cinema”. $G|A| M \mid E, \quad 4$ (2015), retrieved from https://www.gamejournal.it/arsenault_perron_deframing/

Purchese, R., “Take-Two rubbishes Mafia II racism claims”, Eurogamer, 19 agosto 2010, retrieved from https:/www.eurogamer.net/articles/2010-08-19-take-tworubbishes-mafia-ii-racism-claims

Rossen, J., "When the Mob protested the Godfather", Mental Floss, 17 aprile 2017 retrieved from http://mentalfloss.com/article/ 93739/when-mob-protested-godfather 
Santino, U., "La mafia al cinema, tra stereotipi e impegno civile”. In A. Meccia, Mediamafia: Cosa Nostra fra cinema e tv, Trapani: Di Girolamo Editore, 2014.

Santopietro, T., The Godfather Effect, New York: St. Martin's Press, 2012.

Sergi, A., "The Evolution of the Australian 'ndrangheta: An Historical Perspective”, Australian and New Zealand Journal of Criminology, 48 (2014), no. 2: 155-174.

Shannon, C., "Public Enemies, Local Heroes: The Irish-American Gangster Film in Classic Hollywood Cinema”, New Hibernia Review, 9 (2005), no. 4: 48-64.

Shapiro, H., "Rediscovering 'The Immediate Experience' by Robert Warshow”, The Georgia Review, 47 (1993), no. 4: 726-732.

Video games:

Master Designer Software, Inc. The King of Chicago [Amiga, Android, Atari ST, DOS, iPad, iPhone, Macintosh, Sharp X68000]. Cinemawave, 1987. Played in September 2018.

Igelsoft. Mafia. [Commodore 64]. Igelsoft, 1986.

Nintendo Co., Ltd. Hogan's Alley. [Arcade, NES, Wii U]. Nintendo Co., Ltd., 1984.

Seibu Kaihatsu Inc. Empire City: 1931. [Arcade, MSX, NES]. Taito America Corporation, 1986.

Nintendo of America Inc. Gumshoe [NES]. Nintendo Co., Ltd., 1986. Played in September 2018.

Opera Soft S.A. Cosa Nostra [Amstrad CPC, MSX, ZX Spectrum]. Opera Soft S.A., 1986. 
74 Mafia and representation

Seibu Kaihatsu Inc. Dead Angle. [Arcade, SEGA Master System]. FabTek, Inc., 1988.

Atari. Enter the Matrix. [Playstation 2, Microsoft Windows, GameCube, Xbox]. Shiny Entertainment, 2003.

US Gold. The Godfather [Amiga, MS-DOS, Atari ST]. USA, 1991. Played in May 2018.

DMA Design. Grand Theft Auto III. [PS2, Xbox, Windows]. Rockstar Games, USA, 2001. Played October 2017.

Rockstar North. Grand Theft Auto: Vice City. [PS2, Xbox, Windows, Version 2006]. Rockstar Games, USA, 2002. Played in April 2018.

Rockstar North/Rockstar Leeds. Grand Theft Auto: Liberty City Stories [PS Portable, PS2, iOS, Android]. Rockstar Games, USA, 2005.

Gamenesis. Mafia Gambling [Windows, Mac OS]. Gamegenesis, 2018.

Hothouse Creations. Gangsters: Organized Crime. [Windows]. Eidos Interactive, UK, 1998. Played in October 2017.

Hothouse Creations. Gangsters 2: Vendetta. [Windows]. Eidos Interactive, UK, 2001. Played in May 2018.

Nintendo Research \& Development. Gumshoe. [NES]. Nintendo of America Inc., USA, 1986.

Crazy Monkey Studios, Claeysbrothers. Guns, Gore and Cannoli [Windows, Mac OS]. Crazy Monkey Studios, USA, 2015.

IO Interactive. Hitman 2: Silent Assassin [PS2, Xbox, Windows, GameCube]. Eidos Interactive, UK, 2002. 
EA Redwood Shores. The Godfather. [PS2, Xbox, Windows]. Electronic Arts. USA, 2006. Played October 2017.

2K Czech. Mafia II. [PS3, Xbox360, Windows]. 2K Games, USA, 2010. Played in May 2018.

Hangar 13. Mafia III [PS3, Xbox360, Windows, Mac OS] 2K Games, USA, 2016. Played in May 2018.

Haemimont Games. Omerta: The City of Gangsters. Kalypso Media, Germany, FX Interactive, Spain, 2013. Played in December 2017.

Santa Ragione. Wheels of Aurelia. [Linux, Macintosh, Microsoft Windows, Nintendo Switch, PS4, Xbox One]. Santa Ragione, Italy, 2016.

La Molleindustria. Memory Reloaded [Windows]. La Molleindustria, Italy, 2005. Played in May 2018.

Spellbound Entertainment. Chicago 1930 [Windows, Mac OS]. Wanadoo Edition, France, 2003.

Zynga. Mafia Wars. [Windows, Mac OS, miscellaneous mobile device] Zynga, USA, 2009.

Maestri Mob Wars. [Windows, Mac OS, miscellaneous mobile device]. Maestri, USA, 2008.

Radical Entertainment. Scarface: The World Is Yours. [PS2, Xbox, Windows]. Vivendi Games, USA, 2006.

Weappy Studio. This is Police [Windows, OS X, Linux, PS4, Xbox One, Nintendo Switch]. THQ Nordic, Austria, 2016. Played in May 2018. 
76 Mafia and representation

TV series

Bad Blood, City, 2017-ongoing, Canada.

Gomorra - La serie, Sky Atlantic, 2014-ongoing, Italy.

Hombrese de honor, Canal 13, 2005, Argentina.

Peaky Blinders, BBC Two, 2013-ongoing, UK.

Underbelly Files: Infiltration, Nine Network, 2011, Australia.

Films

Gomorra, Matteo Garrone, 2008, Italia.

Hitman, Xavier Gens, 2007, France, USA, UK.

Hitman: Agent 47, Aleksander Bach, 2015, USA.

Pulp Fiction, Quentin Tarantino, 1994, USA.

The Godfather, Francis Ford Coppola, 1972, USA.

The Real Sopranos, Thomas Viner, 2006, UK.

The Valachi Papers, Terence Young, 1972, USA/Italia. 